\title{
To Clear or Not: Examination of Mergers and Acquisition Cases from Small Economies
}

\author{
Bobby Maharaj ${ }^{1} \&$ Mahendra Reddy ${ }^{2}$ \\ ${ }^{1}$ Fiji Commerce Commission, Fiji Islands \\ ${ }^{2}$ Fiji National University, Fiji Islands \\ Correspondence: Mahendra Reddy, Fiji National University, Fiji Islands. E-mail: mahendra.reddy@fnu.ac.fj \\ Received: September 7, 2012 \\ Accepted: December 26, 2012 Online Published: January 11, 2013 \\ doi:10.5539/ijef.v5n2p125 \\ URL: http://dx.doi.org/10.5539/ijef.v5n2p125
}

\begin{abstract}
In an increasingly competitive market, the corporate sectors in small developing countries are adopting a number of strategies to deal with raising efficiency and productivity. One such strategy is consolidation, that is, mergers and acquisitions. One of the primary motive to undertake a merger is to gain the synergy that would accrue from more efficient management, economies of scale and scope, removal of duplication of resources, utilization of resources to their full potential, and improved production techniques. This study examines the basis of mergers and acquisitions (M\&A) and utilizing two recent cases of $M \& A$ applications, provides a theoretical and practical basis to decide on whether mergers and acquisitions will be allowed or not. In doing so, we demonstrate the process and methodologies utilized to assess and examine an M \& A application. The first case involves a conglomerate merger in the beverage industry while the other involves an acquisition in the same industry. In both the cases, the M \& A application was cleared. In the first case, the merger involved two different kinds of beverage activity - alcoholic and soft drinks beverage hence there was no effect on the market share of the individual products. In the second case, while the acquisition was in the same industry, a detailed financial analysis of the acquired firm reveals that it is a "failing firm", and therefore, in the public interest, the acquisition needs to be cleared.
\end{abstract}

Keywords: mergers, acquisitions, failing firm, herfindahl-hirshman index (hhi), public interest

\section{Introduction}

The corporate sector in small developing countries, faced with inherent limitations of market size, externalities and external shocks, is facing major challenges in trying to remain competitive in a dynamic global market. The financial crisis in their major trading-partner countries has left smaller economies such as PICs with major challenges in trying to survive the trickling-in effects of the global fallout from the financial crisis.

Businesses in these small economies have adopted a number of strategies to deal with this scenario including downsizing and right sizing. However, more well established companies have also examined ways in which to reduce unit costs and increase growth and profitability. One such approach has been reorganization and consolidation, that is, mergers and acquisitions.

Mergers are defined as "any amalgamation of the undertaking or any part of the undertaking or interest of two or more companies or the undertaking or part of the undertakings of one or more companies and one or more bodies corporate" (Akinbuli, 2012: 686).

Acquisitions or takeovers, on the other hand, refer to the process of combining two or more firms and in which one firm acquires the assets and liabilities of the other in exchange for cash or shares, goods or debentures (Akinbuli, 2012:686). DePamphilis (2008) described acquisition to mean all the processes, terms, conditions and fulfillment adopted to purchase a small firm by a big and well established unit. These acquisitions can be either full or partial. In a full acquisition, the acquirer buys all the stock and capital of the purchase company while in a partial acquisition, the acquirer obtains a controlling interest, normally above $50 \%$ but below $100 \%$.

The synergic gains from mergers and acquisition activity result in more efficient management, economies of scale and scope, removal of duplication of resources, utilization of resources to their full potential, improved production techniques, combination of complementary resources, redeployment of assets to more profitable uses, and, the exploitation of market power or any number of value enhancing mechanisms that fall under the rubric of 
corporate synergy. However, mergers and acquisitions can also have a major detrimental impact on the economy via their effect on market structure, the subsequent effect on acquiring a dominant position and substantial market power to the firm(s) in the relevant market and thus abuse of this power. Given this issue, mergers and acquisitions have to be cleared by Competition authorities in countries where there are independent Competition Commissions. In the absence of this, the Ministry of Finance or Commerce is charged with examining and approving applications for mergers and acquisitions.

The legislation in Fiji that looks into mergers and acquisitions, Commerce Commission Decree 2010 (vide Section 72 and Section 73), Section 72 stipulates that a merger cannot be authorized if it will substantially lessen competition or result in a monopoly. In determining if a merger is anti-competitive, regulatory agencies look at the markets served and the type of commerce involved. Several factors are considered, such as size of market, number of competing companies and financial condition of companies.

In light of the above regulatory requirement, we undertake a detailed examination of two applications for merger clearance. The first application is by a beverage firm to take over another firm in the same industry while the second application is from a hardware firm to acquire another firm in the same industry. In the following section, we provide an overview of mergers and acquisition literature. In the third section, we examine the two cases in detail and in the fourth section, we provide summary and conclusion.

\section{Mergers and Acquisitions: An Overview}

An organization's decision to merge with or acquire another organization is one that requires a lot of deliberation and consideration. Some of the considerations must involve: why merge? What are the problems associated with merging? How will the currents problems be resolved by a merger and what benefits will the organization derive from the strategy? Schenk (2000) argued that mergers and acquisitions often form part of the strategic options expected to transform company performances. Mergers usually arise when neither company has the scale to acquire the other on its own. While in mergers both firms lose their registering name to become a new company entirely, acquisitions involve the stronger organization swallowing the smaller or weaker one entirely without any changes to the stronger firm's identity. However, this decision to merge or acquire is not an easy decision. It is involves a complex process (Akinbuli and Kelilume, 2013) and requires and great deal of analysis to answer fundamental questions prior to a decision on whether to merge or not. Some of the issues to be dealt with include:

a) How the merger will be financed?

b) What to do with management staff?

c) How many other staff will be laid off and how are they to be compensated?

d) How to handle branding issues.

Some of the above decision to the above questions depends on the type of merger undertaken. The merger literature outlines three common types. The first are the horizontal mergers, which take place between actual and potential competitors in the same product and geographic markets, and at the same level of the production or distribution chain. Vertical mergers, on the other hand, occur where firms that operate at different levels of the production and distribution chain, merge. For example, two companies - a water bottling company and another that owns a retail network with vast distribution capabilities. Herein lies the perfect formula for a successful vertical merger, with the bottling plant concentrating on just extracting and bottling water while the other arm deals with labeling, marketing, distribution and retailing. The different stages of production delivery combine to create more efficiency, more productivity, more profitability and more value. Lastly, a conglomerate merger refers to mergers between companies in unrelated industries or in totally different markets, hence does not pose much of a concern to competition authorities. One objective of such a merger is to create a diversified portfolio which in turn could help in hedging against risk. This type of merger can create some operating efficiencies resulting from the combination and elimination of redundant departments. Mergers and acquisitions, if handled diligently, can become the key strategy for enhancing productivity and profitability. Referring to mergers and acquisition cases in Nigeria, in a recent study, Mandi (2003:3) notes the following:

"In the last three years, growth through acquisition has been a critical part of the success of many companies in the new economy. In fact, I would say that merger and acquisition has been the single most important factor in building up their market capitalization".

While lead firm engaging in this exercise does pursue major gains, policy makers and regulators and concerned about potential negative impact on industry, consumers and the economy. A major concern for policy makers and regulators is the increase in market concentration and therefore, the cumulative economic power of firms 
involved in horizontal mergers. The level of market concentration is the main determinant in measuring the substantial market power and market dominance of a firm. If the merger leads to the creation of a monopoly, the new firm will not face any restrictions from competitors when it takes pricing decisions. Similarly, if the new firm becomes a dominant firm following the merger, then it can unilaterally set prices which others will have to adopt as the market price. For example, two of the three oil companies in Fiji would like to merge because they believe they can create efficiencies within the company and thus eliminate costs and improve profitability. Such mergers raise competition concerns because they may lead to a reduction in the number of rivals in the market, causing increased market concentration. In a study on the impact of mergers on consumer welfare, McAfee and Williams (1992) concluded that mergers, which resulted in a new firm at market and increased the concentration of the largest firm, would always reduce welfare.

There are several firm attributes that are hypothesized to explain why certain firms may be seen as prime candidates for mergers and acquisitions. The first is the size hypothesis. Smaller companies are more likely to become acquired than larger companies (Palepu, 1986; and Walter, 1994).

The authors cite the costs of competition with other bidders and costs associated with adapting the acquired company to the acquirer's culture, as examples of size-related costs. They base their argument on the premise that these costs increase with the size of the acquired company and therefore, that firms acquire those smaller than themselves because the size-related costs of acquisition will be lower.

Mane (1965) also argues, based on the inefficient management hypothesis, that inefficiently managed firms whose managers fail to maximize shareholder wealth, are more likely to be targets for mergers and acquisitions. The financial leverage hypothesis contends that low debt exposure also raises the likelihood of a firm becoming a target for acquisition (Stulz, 1988).

He argues that firms with a high unused debt capacity are regarded as attractive merger targets because low leverage reduces the risk of default and increases the debt capacity of the joint firm.

The liquidity hypothesis argues that the likelihood of being acquired increases with greater liquidity because excess liquidity gives the bidder the opportunity to finance the acquisition with the target firm's own resources (Song and Walkling, 1993).

The growth-resource imbalance hypothesis submits that firms with a mismatch between their growth opportunities and liquid financial resources are regarded as attractive for acquisitions (Palepu, 1986).

Lastly, the asset undervaluation hypothesis argues that firms with low market-to-book ratios are also attractive acquisition targets because they are viewed as undervalued (Hasbrouk, 1985). He suggests that companies that wish to expand through acquisitions compare the cost of new investment with the cost of acquisition of an existing firm and take the cheaper option.

There has been a massive increase in both the number and volume of $\mathrm{M}$ and $\mathrm{A}$ activity across the globe over the past four decades, driven by globalization, technological changes, factor market deregulation and liberalization, pegged on the new growth theory. However, the final story of this wave of $\mathrm{M} \&$ A activity is not all so rosy. There have been a significant number of failures as well. There are a limited number of studies that have examined these cases. A recent study by Chakravorty (2012) identified a set of 30 factors which, if not addressed, could result in the failure of the $\mathrm{M} \& \mathrm{~A}$. A number of studies also highlight lack of cultural due diligence, cross cultural communication, connection and control as a major factor for Multinationals to fail in acquisitions across borders (Rottig, 2007, Askim, et. al., 2008 and Vaara, 2003).

\section{Examination of $\mathrm{M} \& \mathrm{~A}$ Applications}

\subsection{Case I: Beverage Company Merger}

\subsubsection{Background to Case - Coca Cola Amatil vs Foster's Group Pacific Ltd.}

Coca Cola Amatil Limited (CCA): Coca Cola is the world's largest beverage company with more than 500 brands including the highly popular Diet Coke, Coke Zero, Fanta, Sprite and Powerade. It has its affiliate Coca-Cola Amatil (Aust) Pty Ltd, which are both Australian companies, entered into an agreement ("JV Agreement") with SABMiller plc (and its affiliates SABMiller Limited, SABMiller Africa \& Asia BV (collectively "SABMiller") in or around 2006 to establish a joint venture called Pacific Beverages Pty Limited. The company has operations in five countries in the South East Asia/Pacific rim region - Indonesia, Papua New Guinea, Australia, New Zealand and Fiji - manufacturing, selling and distributing a diversified product portfolio including carbonated soft drinks, water, sports and energy drinks, fruit juice, flavoured milk, coffee and packaged ready-to-eat fruit and vegetable products. The Fiji operation is 50 years old. Foster's is an Australian 
company focused on brewing activities through two divisions, Carlton United Brewers $(\boldsymbol{C U} \boldsymbol{B})$ and the Rest of World. CUB is Foster's largest division and the largest brewer in Australia, with almost $50 \%$ volume share of the Australian beer market.

CUB operates the Yatala Brewery in Queensland, the Abbotsford Brewery in Melbourne, the Cascade Brewery in Hobart and a craft beer facility in Melbourne, and produces cider in Campbelltown. It is also the largest brewer in Fiji.

FGPL owns two brewing plants in Fiji, one in Samoa, a distillery in Fiji and a series of well known beer, spirit and Ready-To-Drink brands in the two markets. Fiji Bitter for instance has been brewed since 1957 when Foster's entered Fiji through Carlton United Breweries, and together with its new brand Fiji Gold, commands an $80 \%$ hold on Fiji's beer market.

On 20 June 2011, Foster's received an indicative, non-binding, conditional proposal from SABMiller to acquire all Foster's shares under a scheme of arrangement. Subsequently, on 17 August 2011, SABMiller announced its intention to make a conditional, off-market, cash takeover offer. On 21 September 2011, Foster's Group Limited (Foster's) announced it had entered into the Scheme Implementation Deed under which it is proposed that SABMiller plc (SABMiller), through SABMiller Beverage Investments Pty Limited (its indirect wholly owned Australian subsidiary), will acquire all Foster's shares pursuant to a scheme of arrangement and, subject to receipt of a favourable ATO tax ruling, an equal capital reduction (Transaction).

The JV agreement was amended in 2008, and most recently varied on 20 June 2011 . The 2011 variation gave SABMiller certain rights to purchase the Foster's Group of companies owned by the former Australian listed company Foster's Group Limited. Additionally the 2011 variation gave CCA various rights to purchase certain assets within the Foster's Group either directly or through an affiliate. SABMiller completed its acquisition of the shares in FGL on or about 18 December, 2011, and CCA (and its affiliate) became entitled to purchase FGL's interests in FPGL under a call option. Under the JV Agreement, SABMiller Beverage Investments granted CCA the right, if the Scheme is implemented, to acquire the following assets or operations of the Foster's Group:

(i) The Spirits Brands and the Spirits RTD Brands together with, at CCA's election, to the extent severable, all assets and trading liabilities (including contracts and employees) attributable to the production, marketing, distribution and/or sales of products commercialized under those brands in Australia (including any foreign registrations of those brands) (Spirits Option);

(ii) The non-alcoholic beverages brands (excluding Beer Product and non-alcoholic applications of alcoholic brands other than Cascade), either by way of transfer or exclusive perpetual licence (to the maximum extent possible under applicable laws or contractual terms), together with, at CCA's election, to the extent severable, all assets and trading liabilities (including contracts and employees) wholly attributable to those brands in Australia (NABOption); and

(iii) The beverages businesses in Fiji and the interest in Samoa Breweries Limited (Fiji Option)

Coca-Cola Amatil Limited ("CCA") vide a letter dated 26 March, 2012 through their legal counsel advised the Fiji Commerce Commission ("Commission) that CCA has now exercised its rights to proceed with the acquisition of Foster's Group Pacific Limited ("FPGL") through the acquisition of the $89.6 \%$ shareholding held by Foster's Australia Limited ("FAL") in FPGL for a total share price of A \$ million (cannot disclose amount) for the $89.6 \%$ stake, subject to all regulatory approvals.

\subsubsection{An Examination of the Acquisitions Impact on Competition and Market Outcome}

\subsubsection{Market Definitions}

Relevant Product Market: The first step in analyzing the competitive position of any firm or firms in an industry is to define the relevant market in which the firm operates. In competition law, the relevant market defines the market in which one or more goods compete. Therefore, the relevant market defines whether two or more products can be considered substitute goods and whether they constitute a particular and separate market for competition analysis. In such a conglomerate merger, the two firms involved in the transaction are carrying out business activities in what can be broadly defined as the Beverages Market. However, CCA and FGPL are engaged in two different categories of beverages and as such it is essential to define the relevant product market differently.

CCA Fiji's core activities include production, distribution and export of carbonated and non-carbonated soft drinks. Therefore, CCA Fiji's activities are confined to the non-alcoholic beverages market. Given that, the Commission defines CCA's relevant product market (for the purpose of evaluating this acquisition) as 


\section{"Ready-to-drink soft drinks of a carbonated and non-carbonated nature".}

FGPL on the other hand is involved in the production and distribution of alcoholic beverages. FGPL's major products in the local market include Fiji Bitter, Fiji Gold, Fiji Draught, Fiji Premium, Fiji Taki, Bounty Rum, Regal Gin, Regal Whisky, Zarina Vodka, Bounty Rum, Bulk Rum etc. The Commission's market survey results show FGPL's products such as Fiji Bitter and Fiji Gold account for around 80\% of Fiji's alcoholic beverages market. Based on the Commission's analysis, the Commission has defined the relevant product market for FPGL products as: "That of the distribution of beer and other alcohols in establishments selling alcoholic beverages for consumption".

Relevant Geographic Market: The Commission has adopted to define the geographical extent of a market to include all of the relevant, spatially dispersed sources of supply to which buyers can turn should the prices of local sources of supply be raised. For each good or service combination, the overlapping geographic areas in which the parties operate are identified. Generally, the higher the value of the product to be purchased, in absolute terms or relative to total buyer expenditure as appropriate, the more likely buyers are to travel and shop around for the best buy, and the wider the geographic extent of the market is likely to be. Where transport costs are high relative to the final value of a product, a narrower geographic market is more likely to be appropriate. Where product preservation ability and other similar practical considerations limit the distance that a product may be transported, this may limit the geographic extent of the market. The timeliness of delivery from alternative geographic sources is similarly relevant. Although buyers and sellers of a particular good or service may interact in markets that are apparently local or regional in extent, those markets may themselves overlap and interrelate so as to form a market covering a larger geographical area. In these situations, the larger market is likely to be the appropriate one for analyzing the competitive effects of a business acquisition.

Non-alcoholic and alcoholic beverages are marketed Fiji wide and sold via outlets with a national presence. Distinctions can be made between supermarkets and route trade such as supermarkets, service stations, and dairies in that there is a difference in the way the product is packaged and sold as well as the customer need the product is addressing. Supermarkets stock primarily on-chilled large 'take home' packs of beverage at prices that are significantly below those charged at the route trade, whereas route trade premises target the 'drink now' market with the majority of products sold chilled in single serve packaging. However, supermarkets also have a route trade display, stocking chilled single serve products, and the route trade outlets also stock a limited amount of non-chilled take home packs. Therefore there is no precise distinction between the route trade and the supermarket trade. The geographic market is defined as: "National markets, with no separate sub-markets by type of wholesale and retail outlet".

\subsubsection{Definition of Functional Level}

The production, distribution and sale of a product typically occur through a series of functional levels - for example, the manufacturing/import level, the wholesale/distribution level and the retail level. It is often useful to identify the relevant functional level in describing a market, as a proposed business acquisition may affect one horizontal level, but not others. Alternatively, some acquisitions, such as those involving businesses at different vertical levels, may raise issues related to vertical integration. Generally, the Commission will seek to identify separate relevant markets at each functional level affected by an acquisition and assess the impact of the acquisition on each. CCA is involved in the bottling and wholesaling of non-alcoholic beverages. FGPL on the other hand is involved in the bottling and wholesaling of non-alcoholic beverages. Should market power be expressed post acquisition, it is most likely to be expressed at the wholesale level. Therefore, the Commission concludes that the functional level affected by the proposed acquisition is the wholesale supply of product.

\subsubsection{Change in Holdings Structure}

CCA and FGPL are currently operating as separate legal entities. The current and post merger structure of FGPL are as follows:

\section{Current FGPL: Foster's Australia (89.59\%) and Minority Shareholders (10.41\%)}

Post Acquisition: Coca-Cola Amatil (Fiji) Ltd (89.59\%) and Minority Shareholders (10.41\%)

The Acquisition will not change the number of participants in the Alcoholic Beverages Market. CCA Fiji will simply replace Foster's Group/SABMiller as the majority owner of FGPL. Accordingly, the number of alternatives available to purchasers of alcoholic beverage products in the Alcoholic Beverage Market will remain unchanged. At the date of the application, CCA Fiji and FGPL were not in competition with each other in the market for alcohol beverages in Fiji ("Alcoholic Beverages Market"). As such it does not raise competition concerns. CCA's acquisition of FGPL is a case of a conglomerate merger between two firms in different 
industries; the degree of competition within each industry is largely unaffected.

CCA and FGPL are currently operating in different product markets. This means that the acquisition will not:

(i) affect competition adversely in any relevant market; or

(ii) alter the existing structure of the relevant market; or

(iii) substantially lessen competition within the meaning of section 60 of the Decree; or

(iv) be detrimental to the consumers of Fiji or the Fiji economy ("Adverse Effects").

Because CCA Fiji does not currently compete with FGPL in the Alcoholic Beverages Market:

(i) there is no relevant competitive overlap (i.e. no close substitution) between the non-alcoholic beverages of CCA Fiji and the alcoholic beverages of FGPL which are the subject of the Acquisition; and

(ii) the Acquisition will not, therefore, increase the level of concentration among existing participants in the Alcoholic Beverages Market, or otherwise have any Adverse Effects on the level of competition in that market.

FGPL is the dominant participant in the Alcoholic Beverages Market in Fiji while CCA dominates the Non-Alcoholic Beverages market. CCA Fiji is not a currently a participant in the Alcoholic Beverages Market though it has asked Investment Fiji to permit it to be a participant on an interim basis only.

As CCA Fiji and FGPL do not currently compete with each other in the Alcoholic Beverages Market, the simple effect of the Acquisition would be to replace the existing owner of FGPL with a new owner not currently participating in that market. That is, there is no change to the existing structure of the relevant market.

For this reason, there is no basis to reject the application for Acquisition. In fact, the Acquisition is likely to bring the following benefits to the local economy.

(i) the proposed increases in the real value of exports after the Acquisition;

(ii) the proposed substitution of domestic products for imported goods after the Acquisition; and

(iii) the other relevant matters that relate to the international competitiveness of the Fiji beer industry.

Furthermore, CCA Fiji's current intention is to grow the combined FGPL and existing businesses with a strong export orientation. CCA Fiji believes that this was not a priority for FGL in light of potential conflicts of interest in its markets with Australian based brands. CCA Fiji currently has no such conflicts and regards growing exports of beer and spirits to Australia, New Zealand United States, Asia and European markets as a strategy worthy of pursuit. The acquisition will now make CCA's proposal quite viable, to invest capital ("Investment") into improving FGPL'S production facilities in Fiji enabling it to meet export quality standards and deliver superior everyday product quality and consistency.

CCA Fiji proposes to grow the volume of local Fiji alcohol products to be sold in the Fiji market. This includes increasing the local product portfolio to reduce imported products into Fiji. Any substitution of imports directly benefits Fiji's crucial foreign reserves when consumption of local products substitute foreign sourced products.

CCA Fiji is an internationally recognized company with internationally recognized brands, operating at world class standards in Fiji, and is a long term market participant in Fiji, and the Pacific. The Acquisition will provide an opportunity to provide further recognition of Foster's products in the international market.

Based on the above analysis, the acquisition of FGPL by CCA does not lessen competition and thus will not distort the market solution. In fact, given that both the companies have capital investment which deals with similar supply chain process, there is room for considerable efficiency gains. However, there could be three issues that need to be monitored. The first is that the minority shareholders should not be coerced into selling their shares. Secondly, given that the two products are entirely different, if the company engages in tying and bundling, this will impose severe burdens on those consumers who are not consuming either of the products or whose budget does not permit such bundled purchasing. Lastly, CCA must refrain from engaging in a conduct that restricts retailers from advertising or selling the products at below the RRP.

\subsection{Case II: Hardware Company Merger}

This case refers to the application of one of Fiji's largest hardware companies to acquire another company in the same industry. The analysis below shows the process adopted to reach a decision on whether to allow the acquisition.

\subsubsection{Background of the Hardware Industry}

\subsubsection{The Market Players}

There are six major hardware retail and wholesale outlets that supply a wide range of building products in Fiji. 
These major players include: Vinod Patel, Suncourt, R. C. Manubhai and Company Limited, Kasabias, Carpenters Hardware and GMR Muhammad and Sons Limited. It is noted that R. C. Manubhai is considered to be one of the leading hardware dealers, importers and stockists of structural steel, special steel, industrial valve, pipes and fittings, bronze solid bars and bushings. Vinod Patel is considered to be the largest dealer in hardware retail and export. A survey of the market has revealed that these major operators have also set up their local manufacturing and wholesale businesses in a variety of hardware products. In addition to the six major players, there are two hundred and thirty (230) other players in the market. Of these players, some have only a single branch at a particular geographical location, selling only a few hardware items such as timber, while engaged in trade as small variety shops.

\subsubsection{General Information about the Two Companies}

Vinod Patel and Company Limited: The company is situated in the Fiji Islands, dealing in hardware retail and export for more than 40 years. Since opening its doors in early 1962 with a small outlet in Ba town, the company has grown to become Fiji's largest chain of hardware stores, with 10 branches nationwide. Vinod Patel is a primary exporter of hardware to island nations in the Pacific, making it the leading hardware retailer and exporter in the South Pacific region.

Vinod Patel's Export Division currently provides hardware such as PVC pipes, nails, galvanized pipes, etc and other household products like furniture, homeware, basic food items and clothing, to countries such as Kiribati, Wallis \& Futuna, Tonga, Samoa, Tuvalu, Nauru, Cook Islands, Vanuatu and Samoa.

Vinod Patel has branches in all major towns and cities, employs over 700 staff and has a product range of more than 35,000 items. Branches are in Ba, Labasa, Lautoka, Nadi, Nausori, Rakiraki, Sigatoka, Suva.

In addition, associate manufacturing companies - Ba Industries Limited (BIL) and Tubemakers and Roofmart Limited (TRL) - provide quality roofing nails, galvanized and wire nails, PVC pipes and fittings, metal roofing and walling materials, farm fencing, chain link fence, barbed wire and a complete range of structural and reinforcing steel.

Suncourt Hardware: The company was established in 1979 and became one of Fiji's leading hardware merchants with a number of outlets. Suncourt Hardware also have a wholesale division which wholesales to other hardware merchants in Fiji and supplies to projects and sometimes also exports to other Pacific islands. The company has stocks of all types of building materials, hardware, plumbing, electrical, tools, timber, furniture, doors and other related items. Over the years, the company has shut down a number of its outlets and currently has two branches located in Nabua and Nausori.

\subsubsection{Submissions by Vinod Patel and Company Limited and Suncourt Hardware}

Vinod Patel, through their legal counsel wrote to Fiji's regulatory authority, the Fiji Commerce Commission on February 7, 2011, outlining their proposed purchase of Suncourt. In the letter, the legal counsel of Vinod Patel states that they propose that the acquisition will run as a Division of Vinod Patel. However, the business will be operated in the name of "Suncourt Hardware". The two branches will be run as profit centers independently under the supervision of a representative of Vinod Patel and Company Limited (VPCL).

It is proposed that the Branch Management team will be selected from the present staff and they, together with VPCL's representative will be responsible for running the business in accordance with VPCL business policy and procedure. The two branches (Nabua and Nausori) will be 100\% owned by Vinod Patel. The present Directors and Senior Managers of Suncourt will not be involved in the management and operations of the merged entity.

Suncourt Hardware also made a submission outlining the reasons for its decision to sell off its assets and business to Vinod Patel and Company Limited. Their arguments were based on the following:

(i) Absence of Directors: The company has 4 directors. Two directors have migrated from Fiji, one has died and one is imprisoned. Hence the company lack leadership and direction.

(ii) The company has incurred large trading losses and cash flow losses from 2007 following the coup in December 2006. Losses have been driven by reductions in turnover of $\$ 18 \mathrm{~m}-\$ 20 \mathrm{~m}$ per annum to $\$ 12 \mathrm{~m}$ in 2009 . The company has also been exposed to large credit losses to contractors.

(iii) At 31 December 2010, the company had a net deficiency of capital compared to equity of $\$ 1.4 \mathrm{~m}$ in 2009 and the directors will have to sell the remaining personal properties they have to pay off the creditors.

(iv) The sale of the business is imperative, the direct beneficiaries of which will be the staff members who will retain their jobs, as well as local banks and suppliers. 
Suncourt's submission seems to suggest that it is a Failing Company and which needs to be salvaged.

\subsubsection{Competitive Environment}

Fiji's hardware market has many buyers and sellers, thus providing an appearance of a competitive market. However, actual competition in the market cannot be observed. An earlier in-depth study by the Fiji Commerce Commission (2010) revealed some glaring anti-competitive behaviour by hardware outlets. The key issues were:

(i) Price Fixing: The assessment of the economic market situation and behaviour patterns in marketing campaigns, suggest the opportunity to engage in anti-competitive behaviour such as the existence of price fixing.

(ii) Price Setting: The four large firms collectively hold substantial market power and possess the ability to control the market and hence dictate prices and availability of material amongst the hardware manufacturers, distributors, wholesalers and retailers of hardware products.

(iii) Supply Restriction: The Commission also noted the practice in the steel supply market to restrict certain players such as smaller retail stores, contractors and consumers from directly purchasing large quantities from the manufacturer, namely, Fletcher Pacific Steel (Fiji), a division of Fletcher Building Limited.

Local manufacturers and distributors are exposed to competition from suppliers based in Australia, New Zealand, China, Malaysia, Hong Kong, Indonesia, Europe, North America and Asian countries.

\subsubsection{Market Entry}

In essence, there are no artificial barriers (including tariff and regulatory barriers) imposed by any authority in Fiji, as far as entry into Fiji's hardware sector is concerned. Firms are free to enter and leave the market provided they have the capital for investment in the sector. New entrants are at ease to enter provided they meet all the requirements such as being able to obtain a licence, while existing firms are free to shut down. However, for any mergers and acquisitions, clearance is required from the Fiji Commerce Commission.

Barriers to entry into the hardware market in Fiji would appear to be relatively low. This is because:

(i) The sunk costs involved in setting up a retail outlet are relatively low. The function of retailing requires no specialist point of sale facilities, storage facilities or technological expertise - retailers simply require a shop front, storage facility and access to a supplier;

(ii) There are no regulatory restrictions on entry;

(iii) The main inputs for a retailing business are a shop front, labour and product supply, none of which are scarce;

(iv) While there is likely to be a certain degree of brand loyalty for some products (most likely to be more expensive, long life products), this is unlikely to be strong enough to allow an individual retailer to set substantially higher prices than its competitors;

(v) The minimum efficient scale of operation appears to be relatively low in each sub-market - for example there are a large number of small hardware suppliers across the country;

(vi) The price elasticity of demand would appear to be relatively high as all major competitors place advertisements in newspapers, radios and TV on a daily basis announcing discounted prices for a large range of products. Promotional activity of this kind suggests that a retailer in this market would lose customers if it were not able to match or undercut its competitors price;

(vii) The market appears to be growing - this is evident by the extent of new entries as well as expansion in the market over the past years, and

(viii) There is a high level of actual and potential import competition in the market in terms of product availability and substitutability.

\subsubsection{An Examination of the Merger's Impact on Competition and Market Outcome}

\subsubsection{Exploring Vinod Patel's and Suncourt's Merger Motives}

A firm wanting to pursue a merger and acquisition strategy must have some motive behind it. Berkovitch and Narayanan (1993) argue that there are basically three types of motive: Synergy, Agency and Hubris. They argue that the synergy motive is expected in most cases as this suggests that takeovers occur because of the incremental gains to be obtained. Agency motives are selfish as they prioritize the acquirer's interest over the acquired firm while the Hubris hypothesis suggests that takeovers occur because of an error in valuation of the potential merger. In the following section, this paper addresses the prevailing motive of the merger between Vinod Patel and Suncourt. 
Vinod Patel's Motives: From its point of inception, Vinod Patel worked on a financial plan to generate funds through sales, cost reduction, overhead management and increased productivity and customer service. The company started with humble beginnings with two brothers, who worked in hardware stores until they were capable of setting up a business of their own. Learning from their experience as employees they wanted to improve customer service, competitive pricing and the hardware shopping experience in Fiji. The vision and the dedication of the two brothers' were to lead Vinod Patel into becoming the 'biggest name in hardware' in the South Pacific. The company's motto is to provide its customers, the widest range and highest quality products at competitive and affordable prices.

As Fiji's biggest hardware firm, Vinod Patel has accepted that the 21st century approach to consumers is to become a 'one-stop-shop' and hence the vision of 'progress through diversification'. Vinod Patel aims to be the consumer's complete first choice in products for modern living - from laying the initial foundation of the house, to providing the décor, furnishings and necessities to turn the house into a home.

Considering the competitive retail hardware industry in Fiji, Vinod Patel needs a differentiation strategy that would set it apart from mass retailers. The opportunity to do so came with the merger. Therefore the motives of Vinod Patel to merge are: expansion, diversification, quality and customer satisfaction. The merger will allow Vinod Patel to acquire a greater market share, greater revenue and profit over the same fixed costs such as distribution and infrastructure, using their existing marketing strategies.

Suncourt's Motives: Suncourt has not seen a healthy financial performance and position since 2007. The company has incurred large trading and cash flow losses following the coup in December 2006. Losses have been driven by reductions in turnover from $\$ 18 \mathrm{~m}-\$ 20 \mathrm{~m}$ per annum to $\$ 12 \mathrm{~m}$ in 2009 . The company has also been exposed to large credit losses to contractors.

Suncourt's continued poor performance in the past four years led the auditors to remark in 2008 that: "The ability of the company to continue as a going concern for the foreseeable future depends on the continued financial support by the shareholders".

Based on Suncourt's submission, the company falls within the definition of a "Failing Firm" and the motives for Suncourt to merge were to "salvage the business, pay off its liabilities and obligations, and provide an opportunity for the staff to retain their jobs".

\subsubsection{Competition Issues and Analysis}

As per the Commerce Commission Decree 2010 (vide Section 72 and Section 73) Section 72, a merger cannot be authorized if it will substantially lessen competition or result in a monopoly. In determining if a merger is anti-competitive, regulatory agencies look at the markets served and the type of commerce involved. Several factors are considered, such as size of the market, number of competing companies, the financial condition of companies, etc.

The size of the newly merged company in relation to the market is very important. A common test used by regulatory bodies known as the Herfindahl-Hirshman Index (HHI) is to determine if action should be taken to challenge the merger. The HHI measures the impact the merger will have on increased concentration within the total marketplace. HHI is calculated by summing the squares of individual market shares for all companies and categorizing market concentration into one of the three categories. The three categories are:

Less than 1000: Unconcentrated market, merger is unlikely to result in antitrust* action.

1000 - 1800: Moderate concentration. If the change in the HHI exceeds 100 points, there could be concentration in the marketplace.

Above 1800: Highly concentrated market. If the change in the HHI exceeds 50 points, there are significant anti-trust concerns.

There are six major hardware retail and wholesale outlets that supply a wide range of building products. These major players include: Vinod Patel and Company Limited, Suncourt Hardware, R. C. Manubhai and Company Limited, Kasabias, Carpenters Hardware and G.M.R. Muhammad and Sons Limited. Apart from these major players, the hardware industry in Fiji also has many other smaller retailers applying their trade in the industry.

\section{Market Share and Market Concentration}

The market shares of Vinod Patel, R.C. Manubhai \& Company Ltd, Suncourt, Kasabias Limited, G.M.R. Muhammad \& Sons (PTY) Limited, Carpenters Hardware, and other small retailers has been calculated based on the annual sales figures obtained from the company's annual reports for the purpose of calculating the HHI. The motive behind calculating the $\mathrm{HHI}$ is to determine and decide on the application for merger authorization. The 
results of the analysis are presented in Appendix 1. The results demonstrate that of the total market, Vinod Patel has a market share of $35 \%$ while Suncourt has a market share of $5 \%$. Therefore, with the acquisition, Vinod Patel's market share will rise to $40 \%$. Based on the 2009 market share (as a percentage of total market sales), the Commission calculated the HHI results which are presented in Appendix 2. In summary, results show that Pre-Merger HHI was 2093 which increases to 2443 post merger, a difference of 350 . The HHI still remains within the second category which is the threshold for significant concern.

\section{Examination of Vertical Effects}

Both Vinod Patel and Suncourt have shares in Asian Paints. Asian Paints is India's largest paint company and ranked among the top ten decorative coatings companies in the world with a turnover of INR 66.80 billion. Asian Paints along with its subsidiaries have operations in 17 countries across the world with 23 paint manufacturing facilities, servicing consumers in 65 countries through Berger International, SCIB Paints - Egypt, Asian Paints, Apco Coatings and Taubmans. Asian Paints operates in Fiji under the brand name of Apco Coatings.

The total value of shares for Asian Paints is $\$ 475,000.00$. Of this, fifty one (51\%) percent is held by Asian Paints India and forty nine (49\%) percent is held by local shareholders. The number of shares currently held by Suncourt is $1.8 \%$ and Vinod Patel is $4.6 \%$. Post merger, Vinod Patel's share will increase to $6.45 \%$. Under this scenario, Vinod Patel will own $13.24 \%$ of the domestic shareholding of $49 \%$ (see Appendix 3) and thus will result in the company becoming the second largest domestic shareholder and in turn can have voting rights.

However, based on the results above, the Commission infers that the proposed acquisition of Suncourt by Vinod Patel does not raise any serious vertical competition issues as Vinod Patel will hold only a fraction (less than $10 \%$ ) of shareholding in Asian Paints however it may qualify for or increase its voting rights.

\section{Examining the Acquisition based on the Failing Firm Theory}

The jurisprudence of competition law recognizes what has become known as the 'failing firm doctrine' to sanitise a merger that might otherwise raise competition concerns. The defense first emerged in US law in a 1930 decision; International Shoe v FTC, wherein the US Supreme Court recognized that the acquisition of a failing firm did not violate Section 7 of the Clayton Act (this forms part of the legislation on Competition Law in the US).

Influenced by the US approach, the defence has also found its way into European law albeit in an altered form. As in the US, the European Merger Regulation contains no express recognition of the doctrine, but it has been recognized now in case law and the practice of the European Commission ('EU Commission). In the judgment given by the European Court of Justice ('ECJ') in the case of France v Commission, the ECJ accepted the failing firm test applied by the EU Commission, in approving the merger between the only two German producers of potash.

The Competition Authority in Australia and Canada also recognizes the failing firm doctrine. There is thus no doubt that the failing firm doctrine is widely recognized in competition law jurisprudence, and regardless of whether the doctrine has become part of the case law or enjoys an express statutory recognition, has been applied with a degree of uniformity.

While it is not explicitly stated in Fiji's Competition Law, the failing firm doctrine must be recognized in the public interest as long as the acquired firm would have withdrawn from the market if not taken over by the other firm; the acquirer would gain the market share of the acquired firm if the latter were to exit the market; and, no alternatives were available that were less anti-competitive.

\subsubsection{Is Suncourt Hardware a Failing Firm? An Examination of It Financials}

Suncourt Hardware was established in 1979. It became one of the leading hardware merchants with a number of outlets in Fiji. It quickly spread its operations and opened up branches in Nausori, Suva, Nadi and Pacific Harbour (Sales Contact Office) and also established a Wholesale Division. At that stage the company was involved in import, wholesale, distribution, retail and export in some cases.

The firm started to have major managerial setbacks following the departure of directors. There were four directors, of whom, two directors migrated, one died and one was imprisioned. The void in leadership began to have its toll on the financials of the firm so much so that the auditors in 2009 forewarned of the impending disaster should nothing be done. The audit report noted:

"The ability of the company to continue as a going concern is dependent on several factors, which inter alia include the profitability and cash flows of the company over the next twelve months and the company meeting its debt covenants with the financiers". 
In the following section we examine, in detail, the financial position of the firm which led the auditors to make this statement.

Profitability Ratios: Profitability is the single most important goal of any firm. This section examines the key profitability ratios of Suncourt for the period 2006 to 2009. Full details of the analysis are presented in Appendix 6 . The result of the analysis depicts a very dark picture of the business, indicating that the firm could have been experiencing major financial problems. Apart from the Gross Profit Margin and Operating Expense-to-Sales ratio, all the other four ratios have moved to negative since 2007. The summary results are as follows:

(i) Gross Profit Margin: This indicator shows the gross profit for every dollar of sales. The results reveal that it is on the decreasing trend. This ratio was $18.37 \%$ in 2006 and which fell to $16.89 \%$ in 2009.

(ii) Operating Profit Margin: This indicator shows the operating profit for every dollar of sales. The ratio was $6.03 \%$ in 2006 and which worsened to $-0.38 \%$ in 2009 ;

(iii) Net Profit Margin: This indicator takes all expenses into account including interest paid. It measures the profitability of the business and is an indicator of a company's pricing strategies and how well it controls costs. The net profit margin decreased from 2007, following slight variations in the ratio thereafter. This may be due to abnormal conditions or high expenses.

(iv) Retained Profit Margin: This ratio is a measure of accumulated profits and losses of a company over time against the turnover. Decreases in the levels of retained profit margin are noted over the years.

(v) Profit Mark Up: Profit Mark Up measures the profit earned during the year against the costs involved. It is deduced that profit markup has fallen from 2006 (4.62\%) to negative levels. In 2009, the markup profit recorded was at $-20.48 \%$.

Rate of Return Ratios: The following section deals with Rate of Return ratios. The full results of the analysis are presented in Appendix 7. The results from the analysis again reveal a precarious financial position of the business. In summary, the results are as follows:

(i) The Return on Capital Employed (ROCE): This ratio compares earnings with capital invested in the company taking into account sources of financing. ROCE is used to prove the value of business gains from its assets and liabilities. Over the period 2006 to 2009, ROCE significantly reduced to negative amounts.

(ii) The Return on Total Assets before Tax: This ratio indicates how effectively the assets of the business are working to generate profit. Due to decrease in the operating profit before income tax and total assets, it illustrates that management is ineffectively using its assets to generate earnings. A decline is noted from 2007 (-10.93\%) with a slight improvement in 2009 to $-5.59 \%$ from the previous year of $-11.69 \%$.

(iii) The Return on Total Assets after Tax: This ratio takes into account interest and tax has a fluctuating return. With comparison of 2009 to 2006 , the return on total assets has reduced significantly with a decline from $1.6 \%$ in 2006 which worsened to $-6.93 \%$ in 2009.

(iv) The Return on Fixed Assets: It measures how fixed assets are being used to generate profits. The percentage has decreased from 2007, with a further fall in 2008 (-30.59\%), while a rise was observed in $2009(-12.91 \%)$ due to a lower level of profit before income tax (7.92\%) in 2006 and which worsened to $-12.91 \%$ in 2009 ;

(v) The Return on Working Capital: This ratio gives an indication of the ability of the business to pay its dues. A fluctuating trend was observable in the return for working capital over the period. The return decreased from 2008 to 2009 determining that Suncourt did not have enough working capital to meet its obligations. The percentage was $12.30 \%$ in 2006 and which improved in 2008 to $619.28 \%$ and then declined to $413.77 \%$ in 2009 ;

Liquidity Ratios: There are two ratios that need to be computed to examine the liquidity position of a firm. These two ratios are the Current Ratio and the Acid Test Ratio (see Appendix 8). The current ratio is an indication whether the business is able to meet its liquidity (short term) obligations. Suncourt's current ratio reduced from 1.3441 in 2006 to 1.1877 in 2007 with a further decline in 2008 to 0.9703 with a rise in 2009 to 0.9767. This indicates that Suncourt does not have sufficient current assets to cover its current liabilities, posing the risk of liquidation. The acid test ratio is an indication of the level of liquid assets that can be used to meet short term liabilities and assets to be easily converted into cash. A decreasing trend is notable from $2006(0.8068)$ to 0.5017 in 2009 .

Asset Usage/Efficiency Ratios: The Asset usage ratios aim to demonstrate the how efficiently the assets of the firm are utilized over the years. An increase in the ratio will indicate that the firm is, over the period of time, making better utilization of its assets. In this study, we examine 8 ratios and note that except for two ratios, all the rest reveal a worsening trend with regard to Asset Use Efficiency. Specifically the following is a summary of 
the analysis while full details are presented in Appendix 9.

(i) Total Asset Turnover: The Total Asset Turnover is the amount of sales generated for every dollar's worth of assets. From the year 2006, this ratio declined from 1.3413 to 1.1532 in 2009 . This represents a $14 \%$ decline in Total Assets Turnover in 4 years.

(ii) Fixed Asset Turnover: The Fixed Asset Turnover is the amount of sales generated for every dollar's worth of fixed assets. This ratio declined from 4.7175 in 2006 to 2.6620 in 2009. This represents a decrease of $43.6 \%$ over a four year period.

(iii) Current Asset Turnover: The Current Asset Turnover is the amount of sales generated for every dollar's worth of Current assets. This ratio increased from 1.8742 in 2006 to 2.0347 in 2009.

(iv) Capital Employed Turnover: The Capital Employed Turnover is the amount of sales generated for every dollar's worth of Shareholders Equity Funds. This ratio increased from 4.25 in 2006 to 17.89 in 2009. The increasing ratio is contributed to decreasing sales and Shareholders' equity as due to losses in the last three years, Suncourt has not had a negative retained earnings.

(v) Working Capital Turnover: The Working Capital Turnover is the amount of sales generated for every dollar's worth of Working Capital. This ratio has decreased drastically from 7.32 in 2006 to -85.23 in 2009. This is contributed to decreasing sales and worsening working capital. A negative working capital indicates that the firm's Current Assets are less than its Current Liabilities.

Management Efficiency Ratios: Management's efficiency can be measured in a number ways. One of these is to examine the trend in three key ratios of Stock Turnover, Debtor's Turnover and Creditor's Turnover. The full analysis is presented in Appendix 11. In summary, the results are as follows:

(i) Stock Turnover Ratio: Stock turnover ratio indicates the number of times the stock has been turned over during the period and evaluates the efficiency with which a firm is able to manage its inventory. This ratio has increased significantly in 2009 compared to 2006 . This is a case of high inventory turnover. A too high inventory means higher carrying costs and higher risk of stock becoming obsolete whereas too low inventory may mean the loss of business opportunities.

(ii) Debtors' Turnover Ratio: Indicates the number of times average debtors are turned during the year. The debtors' turnover measured in days for Suncourt increased from 61.67 days in 2006 to 79.02 days in 2009. This indicates that debtors were taking a longer time to pay off their debts. High debtors' turnover ratio (days) implies inefficient management of debtors or less liquid debtors and increases the risk of bad debts.

(iii) Creditors' Turnover: It signifies the average credit period enjoyed by the firm in paying creditors. This ratio increased from 90.98 days in 2006 to 198.49 days in 2009. This low creditors' turnover ratio or a higher credit period ratio signifies that the Suncourt's creditors were not being paid promptly.

Gearing/Leverage Ratio: The gearing ratio compares owner's equity (or capital) to borrowed funds. It is a measure of financial leverage, demonstrating the degree to which a firm's activities are funded by owner's funds versus creditor's funds. Generally, companies with higher leverage as determined by a leverage ratio are thought to be more risky because they have more liabilities and less equity. Suncourt's Gearing Ratio increased by 1049\% in four years, signifying that a significant level of Suncourt's activities are financed through external financing rather than equity financing (Appendix 12). This poses considerable risks to Suncourt's continuance as a Going Concern. The same picture is evident from the examination of the equity payout ratio. This ratio shows how well earnings support the dividend payments. Dividend payout ratios provide valuable insight into a company's dividend policy and can also reveal whether those payments appear "safe" or are in jeopardy of possibly being reduced.

In light of the above analysis, it is clear that Suncourt is a failing firm. The question that arises then is while the proposed acquisition will further strengthen Vinod Patel's market power, should we disallow the merger and let the firm become insolvent or should we allow the acquisition and let Vinod Patel further strengthen its hold in the relevant market? The answer lies in what option will be in the best interests of the public.

Based on the above analysis, the decision on whether the acquisition should be allowed or not will depend on what options will safeguard the public interest best. Reflecting on the above analysis, we note the following three issues:

(i) That the acquisition will further strengthen Vinod Patel's Market Power but not will not alter the market so much that the company will emerge as the single most dominant firm in the sector; 
(ii) That Suncourt Hardware is a "failing firm", and if allowed to continue in its current form, could become financially insolvent within a very short period of time;

(iii) That should the firm become insolvent, the closure of the firm would result in hundreds of job losses and absence of any supply of hardware products from its Nabua branch while supply from Nausori Branch would also fall signicantly.

Taking the above issues into account, it is clear that the public interest will be better protected with the acquisition being allowed to proceed.

\section{Summary and Conclusion}

This study examines the basis of mergers and acquisition and utilizes two recent cases of applications for M \& A to provide a detailed methodology to examine the applications for a decision.

Mergers and Acquisitions are strategies to reduce unit costs, increase growth and profitability of firms. In this study, we demonstrate that the motive behind both the Mergers and Acquisition were Synergy rather than Agency or Hubris. The synergic gains by mergers and acquisitions activity accrue from more efficient management, economies of scale and scope, removal of duplication of resources, utilization of resources to their full potential, improved production techniques, combination of complementary resources, redeployment of assets to more profitable uses, the exploitation of market power or any number of value enhancing mechanisms that fall under the rubric of corporate synergy. Both the companies, Coca Cola Amatil and Vinod Patel, already have significant expertise in the acquired business area and infrastructure on the ground to achieve economies of scale and scope.

However, mergers and acquisitions can also have major detrimental impact on an economy via their effect on market structure, their subsequent effect on acquiring a dominant position and substantial market power to the firm(s) in the relevant market and thus abuse of this power. Given this issue, mergers and acquisitions have to be cleared by Competition authorities is countries where there are independent Competition Commissions.

In this paper, we have demonstrated the process and methodologies utilized to access and examine a M \& $\mathrm{A}$ application. In doing so, we examined two recent cases in Fiji. The first case involves a conglomerate merger in the beverage industry while the other involves acquisition in the same industry.

In both the cases, the M \& A applications were cleared. In the first case, the merger involved two different finds of beverage activity - alcoholic and soft drinks - hence there would be no effect on the market share of the individual products. In the second case, while the acquisition was in exactly the same industry, a detailed financial analysis of the acquired firm reveals that it is a "failing firm", and therefore, in the public interest, that the acquisition was cleared.

\section{References}

Akinbuli, S. F. (2012). Critical Analysis of the effect of Mergers and Acquisitions on Corporate Growth and Profitability. Global Conference on Business and Finance Proceedings, 7(1), 684-697.

Akinbuli, S. F., \& Kelilume, I. (2013). The Effects of Mergers and Acquisitions on Corporate Growth and Profitability: Evidence From Nigeria. Global Journal of Business Research, 7(1), 43-58.

Askim, J., Christensen, T., Fimreite, A. L., \& Laegreid, P. (2008). Implementation of Merger: Lessons from the Norwegian Welfare Bureaucracy. memeo, University of Oslo, Scandinevian, pp. 29,

Berkovitch, E., \& Narayanan, M. P. (1993). Motives for Takeovers: An Empirical Investigation. Journal of Financial and Quantitative Analysis, 28(3), 347-363. http://dx.doi.org/10.2307/2331418

Chakravorty, J. N. (2012). Why do Mergers and Acquisitions quite often Fail?. Advances in Management, 5(5), 21-28.

DePamphilis, Donald. (2008). Mergers, Acquisitions, and Other Restructuring Activities, 40. New York: Elsevier, Academic Press.

Hasbrouk, J. (1985). The characteristics of takeover targets: Q and other measures. Journal of Banking and Finance, 9(3), 351-362. http://dx.doi.org/10.1016/0378-4266(85)90038-X

Mandi, A. (2003). Lessons from Master Acquirers: A CEO Roundtable on making Merger Succeed. Harvard Business Review, 23(2), 23-32.

Manne, H. G. (1965). Mergers and the Market for Corporate Control. The Journal of Political Economy, 73(2), 110-120. http://dx.doi.org/10.1086/259000 
McAfee, R. Preston, \& Williams, M. A. (1992). Horizontal Mergers and Antitrust Policy. The Journal of Industrial Economics, 40(2), 181-187. http://dx.doi.org/10.2307/2950509

Palepu, K. G. (1986). Predicting Takeover Targets: A Methodological and Empirical Analysis. Journal of Accounting and Economics, 8(1), 3-35. http://dx.doi.org/10.1016/0165-4101(86)90008-X

Schenk, H. (2000). Mergers Efficiency Choice and International Competitiveness, Cheltenhan; Edward Elgar.

Song, M. H., \& Walkling, R. A. (1993). The impact of managerial ownership on acquisition attempts and target shareholder wealth.Journal of Financial and Quantitative Analysis, 28(4), 439-457. http://dx.doi.org/10.2307/2331159

Stulz, R. M. (1988) Managerial control of voting rights: Financing policies and the market for corporate control.Journal of Financial Economics, 20(1-2), 25-54. http://dx.doi.org/10.1016/0304-405X(88)90039-6

Vaara, E. (2003). On the discursive construction of success/failure in narrative of post merger integration. Organisational Studies, 23(2), 211-248.

Walter, R. M. (1994). The usefulness of current cost information for identifying takeover targets and earning above average stock returns. Journal of Accounting, Auditing and Finance, 9(2), 349-377.

\section{Appendices}

Appendix 1. Market Share of Hardware Retailers in Fiji based on Annual Sales Figures

\begin{tabular}{lcccccc}
\hline Market Share & $\mathbf{2 0 0 9}$ & $\mathbf{2 0 0 8}$ & $\mathbf{2 0 0 7}$ & $\mathbf{2 0 0 6}$ & $\mathbf{2 0 0 5}$ & Ratio (2009) \\
\hline GMR & $\$ 15,858,338$ & $\$ 13,953,980$ & $\$ 13,377,787$ & $\$ 14,787,145$ & $\$ 12,883,765$ & $7 \%$ \\
Kasabias & $\$ 18,704,385$ & $\$ 11,819,729$ & $\$ 10,185,732$ & $\$ 11,675,657$ & $\$ 9,055,935$ & $8 \%$ \\
Carpenters Hardware & $\$ 27,881,451$ & $\$ 30,859,716$ & $\$ 28,388,413$ & $\$ 34,367,060$ & $\$ 35,619,775$ & $12 \%$ \\
R C Manubhai & $\$ 45,000,000$ & $\$ 47,000,000$ & $\$ 51,000,000$ & $\$ 57,000,000$ & $\$ 63,840,000$ & $19 \%$ \\
Vinod Patel & $\$ 84,314,608$ & $\$ 76,808,680$ & $\$ 70,797,117$ & $\$ 67,747,194$ & $\$ 61,497,056$ & $35 \%$ \\
Suncourt & $\$ 12,048,521$ & $\$ 15,561,732$ & $\$ 14,606,527$ & $\$ 20,224,750$ & $\$ 19,114,538$ & $5 \%$ \\
Other Retailers & $\$ 36,610,940$ & $\$ 34,992,970$ & $\$ 33,622,227$ & $\$ 36,764,825$ & $\$ 35,815,806$ & $15 \%$ \\
Total Sales & $\$ 240,418,243$ & $\$ 230,996,807$ & $\$ 221,977,803$ & $\$ 242,566,631$ & $\$ 237,826,875$ & $100 \%$ \\
\hline
\end{tabular}

\section{Appendix 2. HHI}

Step 1: Calculate the Pre- Merger HHI

\begin{tabular}{lcc}
\hline Company & & HHI \\
\hline GMR & $7 * 7$ & $\mathbf{4 9}$ \\
Kasabias & $8 * 8$ & $\mathbf{6 4}$ \\
Carpenters & & $\mathbf{1 4 4}$ \\
Hardware & $12 * 12$ & \\
R C Manubhai & $19 * 19$ & $\mathbf{3 6 1}$ \\
Vinod Patel & $35 * 35$ & $\mathbf{1 2 2 5}$ \\
Suncourt & $5 * 5$ & $\mathbf{2 5}$ \\
Other Retailers & $15 * 15$ & $\mathbf{2 2 5}$ \\
Pre-Merger HHI & & $\mathbf{2 0 9 3}$ \\
\hline
\end{tabular}

Step 2: Calculate the Post-Merger HHI

\begin{tabular}{lcc}
\hline Company & & HHI \\
\hline GMR & $7 * 7$ & $\mathbf{4 9}$ \\
Kasabias & $8 * 8$ & $\mathbf{6 4}$ \\
Carpenters Hardware & $12 * 12$ & $\mathbf{1 4 4}$ \\
R C Manubhai & $19 * 19$ & $\mathbf{3 6 1}$ \\
Vinod Patel/Suncourt & $40 * 40$ & $\mathbf{1 6 0 0}$ \\
Other Retailers & $15 * 15$ & $\mathbf{2 2 5}$ \\
Post-Merger HHI & & $\mathbf{2 4 4 3}$ \\
\hline
\end{tabular}

Appendix 3. Pre-Merger Vs Post Merger Shares in Asian Paints

\begin{tabular}{|c|c|c|c|c|c|c|}
\hline \multicolumn{4}{|c|}{ Pre-Merger } & \multicolumn{3}{|c|}{ Post-Merger } \\
\hline Company & $\begin{array}{l}\text { Number of } \\
\text { Shares }\end{array}$ & $\begin{array}{l}\text { Total Share Value of } \\
\text { Paints Issued Capital(\%) }\end{array}$ & Asian & Company & $\begin{array}{l}\text { Number of } \\
\text { Shares }\end{array}$ & $\begin{array}{l}\text { Total Share Value of Asian } \\
\text { Paints Issued capital (\%) }\end{array}$ \\
\hline $\begin{array}{l}\text { Vinod } \\
\text { Patel }\end{array}$ & 21,875 & $4.6 \%$ & & VPCL/Suncourt & 30,625 & $6.45 \%$ \\
\hline Suncourt & 8,750 & $1.8 \%$ & & & & \\
\hline
\end{tabular}

Appendix 4. Top 5 Shareholders of Asian Paints

\begin{tabular}{lcc}
\hline Name of Company/Business & Number of Shares Held & Percentage Shareholding \\
\cline { 1 - 2 } Asian Paints (International) Limited & 243,695 & 51.3 \\
Fijian Holdings Limited & 42,655 & 8.98 \\
Vinod Patel/Suncourt & 30,625 & 6.45 \\
RC Manubhai & 26,250 & 5.53 \\
Arvind Kasabia & 25,463 & 5.37 \\
\hline
\end{tabular}


Appendix 5. Suncourt (Wholesalers) Limited: Profitability Ratios for the period ending 31 December 2006 to 2009

\begin{tabular}{|c|c|c|c|c|}
\hline Ratio & 2006 & 2007 & 2008 & 2009 \\
\hline \multirow{3}{*}{ Gross Profit Margin } & $3,715,374$ & $2,607,976$ & $2,628,348$ & $2,034,960$ \\
\hline & $20,224,750$ & $14,606,527$ & $15,561,732$ & $12,048,521$ \\
\hline & $18.37 \%$ & $17.85 \%$ & $16.89 \%$ & $16.89 \%$ \\
\hline \multirow{3}{*}{ Operating Profit Margin } & $1,218,942$ & $(632,952)$ & $(1,112,729)$ & $(46,310)$ \\
\hline & $20,224,750$ & $14,606,527$ & $15,561,732$ & $12,048,521$ \\
\hline & $6.03 \%$ & $-4.33 \%$ & $-7.15 \%$ & $-0.38 \%$ \\
\hline \multirow{3}{*}{ Net Profit Margin } & 241,393 & $(741,207)$ & $(1,075,920)$ & $(724,488)$ \\
\hline & $20,224,750$ & $14,606,527$ & $15,561,732$ & $12,048,521$ \\
\hline & $1.19 \%$ & $-5.07 \%$ & $-6.91 \%$ & $-6.01 \%$ \\
\hline \multirow{3}{*}{ Retained Profit Margin } & $(2,907,865)$ & 271,520 & $(804,400)$ & $(691,886)$ \\
\hline & $20,224,750$ & $14,606,527$ & $15,561,732$ & $12,048,521$ \\
\hline & $-14.38 \%$ & $1.86 \%$ & $-5.17 \%$ & $-5.74 \%$ \\
\hline \multirow{3}{*}{ Profit Mark up } & 241,393 & $(741,207)$ & $(1,075,920)$ & $(724,488)$ \\
\hline & $5,223,920$ & $4,397,978$ & $4,354,904$ & $3,537,403$ \\
\hline & $4.62 \%$ & $-16.85 \%$ & $-24.71 \%$ & $-20.48 \%$ \\
\hline \multirow[t]{3}{*}{ Operating Expenses to Sales } & $4,344,677$ & $3,580,671$ & $3,869,290$ & $2,995,050$ \\
\hline & $20,224,750$ & $14,606,527$ & $15,561,732$ & $12,048,521$ \\
\hline & $21.48 \%$ & $24.51 \%$ & $24.86 \%$ & $24.86 \%$ \\
\hline
\end{tabular}

Appendix 7. Suncourt (Wholesalers) Limited: Rate of Return Ratios for the period ending 31 December 2006 to 2009

\begin{tabular}{|c|c|c|c|c|}
\hline Ratio & 2006 & 2007 & 2008 & 2009 \\
\hline \multirow{3}{*}{ Return on Capital Employed (ROCE) } & 241,393 & $(741,207)$ & $(1,075,920)$ & $(724,488)$ \\
\hline & $4,763,065$ & $3,204,113$ & $2,128,193$ & 673,498 \\
\hline & $5.07 \%$ & $-23.13 \%$ & $-50.56 \%$ & $-107.57 \%$ \\
\hline \multirow{3}{*}{ Return on Total Assets before Tax (ROTA) } & 339,699 & $(1,450,259)$ & $(1,598,343)$ & $(584,250)$ \\
\hline & $15,078,538$ & $13,263,793$ & $13,670,547$ & $10,447,562$ \\
\hline & $2.25 \%$ & $-10.93 \%$ & $-11.69 \%$ & $-5.59 \%$ \\
\hline \multirow{3}{*}{ Return on Total Assets after Tax (ROTA) } & 241,393 & $(741,207)$ & $(1,075,920)$ & $(724,488)$ \\
\hline & $15,078,538$ & $13,263,793$ & $13,670,547$ & $10,447,562$ \\
\hline & $1.60 \%$ & $-5.59 \%$ & $-7.87 \%$ & $-6.93 \%$ \\
\hline \multirow{3}{*}{ Return on Fixed Assets (ROFA) } & 339,699 & $(1,450,259)$ & $(1,598,343)$ & $(584,250)$ \\
\hline & $4,287,173$ & $4,909,594$ & $5,224,593$ & $4,526,114$ \\
\hline & $7.92 \%$ & $-29.54 \%$ & $-30.59 \%$ & $-12.91 \%$ \\
\hline \multirow{3}{*}{ Return on Working Capital (ROWC) } & 339,699 & $(1,450,259)$ & $(1,598,343)$ & $(584,250)$ \\
\hline & $2,762,460$ & $1,320,484$ & $(258,095)$ & $(141,201)$ \\
\hline & $12.30 \%$ & $-109.83 \%$ & $619.28 \%$ & $413.77 \%$ \\
\hline
\end{tabular}

Appendix 8. Suncourt (Wholesalers) Limited: Liquidity Ratio's for the period ending 31 December 2006 to 2009

\begin{tabular}{|c|c|c|c|c|}
\hline Ratio & 2006 & 2007 & 2008 & 2009 \\
\hline \multirow{3}{*}{ Current Ratio } & $10,791,365$ & $8,354,199$ & $8,445,954$ & $5,921,448$ \\
\hline & $8,028,905$ & $7,033,715$ & $8,704,049$ & $6,062,649$ \\
\hline & 1.3441 & 1.1877 & 0.9703 & 0.9767 \\
\hline \multirow{3}{*}{ Acid Test Ratio } & $6,478,051$ & $3,738,114$ & $4,727,090$ & $3,041,499$ \\
\hline & $8,028,905$ & $7,033,715$ & $8,704,049$ & $6,062,649$ \\
\hline & 0.8068 & 0.5315 & 0.5431 & 0.5017 \\
\hline
\end{tabular}


Appendix 9. Suncourt (Wholesalers) Limited: Asset Usage/Efficiency Ratios for the period ending 31 December 2006 to 2009

\begin{tabular}{lcccc}
\hline Rate & $\mathbf{2 0 0 6}$ & $\mathbf{2 0 0 7}$ & $\mathbf{2 0 0 8}$ & $\mathbf{2 0 0 9}$ \\
\hline \multirow{2}{*}{ Total Asset Turnover } & $20,224,750$ & $14,606,527$ & $15,561,732$ & $12,048,521$ \\
& $15,078,538$ & $13,263,793$ & $13,670,547$ & $10,447,562$ \\
& $\mathbf{1 . 3 4 1 3}$ & $\mathbf{1 . 1 0 1 2}$ & $\mathbf{1 . 1 3 8 3}$ & $\mathbf{1 . 1 5 3 2}$ \\
\hline \multirow{2}{*}{ Fixed Asset Turnover } & $20,224,750$ & $14,606,527$ & $15,561,732$ & $12,048,521$ \\
& $4,287,173$ & $4,909,594$ & $5,224,593$ & $4,526,114$ \\
& $\mathbf{4 . 7 1 7 5}$ & $\mathbf{2 . 9 7 5 1}$ & $\mathbf{2 . 9 7 8 6}$ & $\mathbf{2 . 6 6 2 0}$ \\
\hline \multirow{2}{*}{ Current Asset Turnover } & $20,224,750$ & $14,606,527$ & $15,561,732$ & $12,048,521$ \\
& $10,791,365$ & $8,354,199$ & $8,445,954$ & $5,921,448$ \\
& $\mathbf{1 . 8 7 4 2}$ & $\mathbf{1 . 7 4 8 4}$ & $\mathbf{1 . 8 4 2 5}$ & $\mathbf{2 . 0 3 4 7}$ \\
\hline \multirow{2}{*}{ Capital Employed Turnover } & $20,224,750$ & $14,606,527$ & $15,561,732$ & $12,048,521$ \\
& $4,763,065$ & $3,204,113$ & $2,128,193$ & 673,498 \\
\hline \multirow{2}{*}{ Working Capital Turnover } & $\mathbf{4 . 2 5}$ & $\mathbf{4 . 5 6}$ & $\mathbf{7 . 3 1}$ & $\mathbf{1 7 . 8 9}$ \\
\hline
\end{tabular}

Appendix 10. Suncourt (Wholesalers) Limited: Management Efficiency Ratio's for the period ending 31 December 2006 to 2009

\begin{tabular}{lcccc}
\hline Ratio & $\mathbf{2 0 0 6}$ & $\mathbf{2 0 0 7}$ & $\mathbf{2 0 0 8}$ & $\mathbf{2 0 0 9}$ \\
\hline \multirow{2}{*}{ Stock Turnover } & $4,313,314$ & $4,464,699.50$ & $4,167,473.50$ & $3,299,405.50$ \\
& 55,410 & 40,018 & 42,635 & 33,010 \\
& $\mathbf{7 7 . 8 4}$ & $\mathbf{1 1 1 . 5 7}$ & $\mathbf{9 7 . 7 5}$ & $\mathbf{9 9 . 9 5}$ \\
\hline \multirow{2}{*}{ Debtors' Turnover } & $3,417,361.00$ & $2,823,193$ & $2,676,883$ & $2,608,367$ \\
& 55,410 & 40,018 & 42,635 & 33,010 \\
& $\mathbf{6 1 . 6 7}$ & $\mathbf{7 0 . 5 5}$ & $\mathbf{6 2 . 7 9}$ & $\mathbf{7 9 . 0 2}$ \\
\hline \multirow{2}{*}{ Creditors' Turnover } & $5,190,011$ & $4,839,866$ & $5,415,867$ & $4,989,360$ \\
& 57,048 & 33,702 & 32,976 & 25,136 \\
& $\mathbf{9 0 . 9 8}$ & $\mathbf{1 4 3 . 6 1}$ & $\mathbf{1 6 4 . 2 4}$ & $\mathbf{1 9 8 . 4 9}$ \\
\hline
\end{tabular}

Appendix 11. Suncourt (Wholesalers) Limited: Gearing/Leverage Ratio's for the period ending 31 December 2006 to 2009

\begin{tabular}{|c|c|c|c|c|}
\hline Ratio & 2006 & 2007 & 2008 & 2009 \\
\hline \multirow{3}{*}{ Gearing } & $2,286,568$ & $3,025,965$ & $2,838,307$ & $3,711,417$ \\
\hline & $4,763,065$ & $3,204,113$ & $2,128,191$ & 673,496 \\
\hline & 0.4801 & 0.9444 & 1.3337 & 5.5107 \\
\hline \multirow[t]{3}{*}{ Equity ratio } & $4,763,065$ & $3,204,113$ & $2,128,193$ & 673,498 \\
\hline & $15,078,538$ & $13,263,793$ & $13,670,547$ & $10,447,562$ \\
\hline & 0.3159 & 0.2416 & 0.1557 & 0.0645 \\
\hline
\end{tabular}

Appendix 12. Suncourt (Wholesalers) Return on Investment Ratios for the period ending 31 December 2006 to 2009

\begin{tabular}{|c|c|c|c|c|}
\hline Ratio & 2006 & 2007 & 2008 & 2009 \\
\hline \multirow{3}{*}{ Earnings per share } & 241,393 & $(741,207)$ & $(1,075,920)$ & $(724,488)$ \\
\hline & $1,365,384$ & $1,365,384$ & $1,365,384$ & $1,365,384$ \\
\hline & 0.18 & $(0.54)$ & $(0.79)$ & $(0.53)$ \\
\hline \multirow[t]{3}{*}{ Dividend payout ratio } & $4,000,000$ & - & - & - \\
\hline & 241,393 & $(741,207)$ & $(1,075,920)$ & $(724,488)$ \\
\hline & 16.57 & - & - & - \\
\hline
\end{tabular}

